\title{
DESIGN AND ANALYSIS OF DECISION SUPPORT INFORMATION SYSTEM TO DETERMINE THE PRIORITY OF SELECTING NATURAL DISASTER BARRACK POLICIES WITH THE FUZZY SIMPLE ADDITIVE WEIGHTING METHOD
}

\author{
Muh. Wahid A. Riza ${ }^{1}$, Sholeh Hadi Pramono ${ }^{2}$, Rahmadwati ${ }^{3}$ \\ Department of Electrical Engineering ${ }^{1,2,3}$ \\ Universitas Brawijaya \\ Malang, Indonesia \\ rizaelwahid@gmail.com¹, sholehpramono@ub.ac.id ${ }^{2}$,rahma@ub.ac.id ${ }^{3}$
}

\begin{abstract}
The lack of a disaster information system nowadays has made it difficult to find out information in the disaster area. Making information systems in disaster areas is important to solve the problem of uneven distribution of aid provided at each barrack. Because the conditions of each barrack are different, a system is needed to determine the priority for selecting disaster. To be able to determine the recommendations for the selection of disaster barracks, this study uses the Fuzzy Simple Additive Weighting (Fuzzy SAW) method, uses fuzzy method to determine the input basis value to SAW [3]. With the implementation of the Fuzzy SAW method, the results of this study can provide recommendations for Badan Penangguangan Bencan Daerah (BPBD) of Malang to determine the priority of disaster barracks that can take precedence.
\end{abstract}

Keywords - Information Systems, Disasters, Priorities, Fuzzy, Simple Additive Weighting.

\section{INTRODUCTION}

Geographically and geologically, Indonesia is located in a disaster-prone region, both natural disasters such as earthquakes, floods, landslides, volcanic eruptions, storms, tsunamis, forest and land fires, and non-natural disasters such as technological failures, modernization failures, epidemics and disease outbreaks. According to DIBI, Data Informasi Bencana Indonesia on the BNPB website, the number of natural disasters during 2018 in Indonesia was 2,572 and the number of natural disasters over the past five years was 10,406 [1]

Making information systems in disaster areas is important to solve the problem of unequal aid at each barrack, stacking of aid at a certain area but there is a lack of aid at other areas, there is a shortage of certain commodities or vice versa the aid provided is too much, and less useful. These problems are caused by lack of information regarding disaster victim data and lack of information on aid data that has been provided. Nothingness of such information makes it difficult to determine the priority of countermeasures that should be done with the condition of different needs of each barrack.

To overcome the problems described earlier, need to build an information system that can be accessed online using a web browser and web server. In addition to being able to provide recommendations for disaster management decisions, the Fuzzy Simple Additive Weigting method is used in its development.

\section{LITERATURE REVIEW}

\section{A. Information Systems}

Definition of the system consists of a system based approach that emphasizes the procedures and systems that emphasize the elements. Systems approach that emphasizes the procedure can be defined as a network consisting of procedures that are interconnected, then gather together to complete activities and achieve a certain goal. While the system that emphasizes the elements defined as elements are integrated with the same purpose to achieve the expected goals. So it can be concluded that the system is an element or procedures that are arranged and integrated with a common goal to achieve certain goals. An information system has characteristics including system components, boundaries, the environment outside the system, connectors, inputs, outputs, processing and the goals and objectives of the system [2].

\section{B. Decision Support System}

Decision support system is a system that helps decision makers to complete information from data that has been processed by the relevant and needed to make decisions about a problem more quickly and accurately. The purpose of making a decision support system [2], namely:

1. Make it easier for people to decision-making on issues that semi or unstructured.

2. Provide support for decision making for managers at all levels to help integration between levels.

3. Improving the effectiveness of managers in decisionmaking and not an increase inefficiency.

\section{Fuzzy Multi Attribute Decision Making}

In particular in multi-attribute decision making models can be explained as follows :

For example : $A=\left\{a_{i} \mid i=1, \ldots, n\right\}$ namely an alternative set of decision makers and $C=\left\{\mathrm{c}_{j} \mid \mathrm{j}=1, \ldots, m\right\}$ is the set of objectives desired, then the alternative set $x^{0}$ must be determined which has the highest degree of expectation curve towards the desired goal $c_{\mathrm{j}}[3]$

It can be concluded that the multi attribute decision making (MADM) problem is by evaluating alternative $m: A=$ $(i=1,2, \ldots, m)$, where each attribute is independent of one 
another. A decision matrix for each alternative to each attribute $\mathrm{X}$ is given as follows:

$$
X=\left[\begin{array}{cllc}
x_{11} & x_{12} & \cdots & x_{1 n} \\
x_{21} & x_{22} & \cdots & x_{2 n} \\
\vdots & \vdots & & \vdots \\
x_{m 1} & x_{m 2} & \cdots & x_{m n}
\end{array}\right]
$$

Where $x_{i j}$ is the $i$-alternative performance rating for the $j$ attribute. Weights that indicate the relative importance of each attribute, are given as $W$ :

$$
W=\left\{w_{1^{\prime}}, w_{2^{\prime}}, \ldots, w_{\mathrm{n}}\right\}
$$

Values in weights (W) can be formed into a formula:

$$
\frac{X_{n}}{(X t-1)}
$$

Where:

$X_{n}=$ n-variable $(0-\mathrm{n})$

$X_{t}=$ Total variable in 1 record

Performance rating $(\mathrm{X})$, and weight value $(\mathrm{W})$ are the main values that explain the absolute preference for decision support. MADM problems must be ended by using the ranking process in order to produce the best decision in accordance with all the preference values that have been given.

There are several methods that can be used to solve MADM problems, among others [4]:

1. Simple Additive Weighting (SAW)

2. Weighting product (WP)

3. ELECTRE

4. Technique for Order Preference by Similarity to Ideal Solution (TOPSIS)

5. Analytic Hierarchy Process (AHP).

\section{Fuzzy Database Model Tahani method}

This Fuzzy Database Models Tahani still use the Data Base Management System (DBMS) standard relationship, only this model using fuzzy set theory to obtain information on his query [5]. Tahani describing a query processing method based on a fuzzy with the manipulation of language known as SQL. Fuzzy database models tahani is made up of stages, [6]:

1. Linear Representation, Triangle Curve Representation, Trapezoid Curve Representation Each of these functions will produce values between "0" and "1" in different ways, according to the type of representation used. $f \mu S$ is a membership function of an element in the $\mathrm{S}$ set, then for an element $\mathrm{X}$ it can be stated $\mu \mathrm{S}(\mathrm{X})$ which has a value between " 0 " and "1" so there are nthree possibilities: $\mu \mathrm{S}(\mathrm{X})=1 \rightarrow \mathrm{X}$ absolute members of $\mathrm{S}$, $\mu S(X)=0 \rightarrow X$ absolute is not a member of $S, \mu S(X)$ $<1 \rightarrow \mathrm{X}$ members $\mathrm{S}$ with degrees of membership between 0 and 1 .

2. Fuzzyfication is the first phase of fuzzy calculation, namely the conversion of firm values to fuzzy values. The process is as follows: an analog quantity is entered as an input (crisp input), then the input is entered at the scope / dominant limit of the membership function. This membership function is usually called the membership function input. The output of this fuzzification process is a fuzzy input value or what is usually called a fuzzy input.

3. Fuzzyfication Query is assumed to be a conventional (nonfuzzy) DBMS query that will try to create and implement a basic system of fuzzy logic queries (fuzzy logic based querting system). The concept of a fuzzy relation in a DBMS uses the degree of membership $\mu$ which is defined in the domain set $\mathrm{X}=(\mathrm{X} 1, \ldots, \mathrm{Xn})$, and has been generated in an external relation by the fuzzy middle value. The query syntax used is as follows: "select from where".

4. Zadeh's Basic Operators for Fuzzy set Operations in a conventional set, there are several operations that are specifically identified to combine and modify fuzzy sets. The membership value as of 2 fuzzy sets is known as Fire Strength or $\alpha$-predicate. It is entirely possible to use basic operators in the query process in the form of AND and OR operators. $\alpha$ - predicate as a result of operations with the AND operator is obtained by taking the smallest membership value among the elements in the sets are concerned, denoted : $\mu \mathrm{A} \cap \mathrm{B}=\min (\mu \mathrm{A}[\mathrm{x}], \mu \mathrm{B}[\mathrm{x}])$. As for operating results with an OR operator is obtained by taking the largest membership among the elements in the sets are concerned, denoted: $\mu \mathrm{AUB}=\max (\mu \mathrm{A}[\mathrm{x}]$, $\mu \mathrm{B}[\mathrm{x}])$. Recommended alternative is an alternative that has a Fire Strength value or the level of compliance with the criteria selected above 0 up to number 1 .

\section{E. Simple Additive Weighting}

The Simple Additive Weighting (SAW) method is often also known as the weighted sum method. The basic concept of the Fuzzy SAW method is to find a weighted sum of the performance ratings for each alternative on all attributes. SAW can be considered as the easiest and most intuitive way to handle the Multiple Criteria Decision Making MCDM problem, because linear additive functions can represent decision maker preferences. This can be justified, however, only when the assumption of preference independence or preference separability is fulfilled [7].

SAW method, because of its simplicity, is the most popular method in the MADM problem and the best alternative may be derived from the following equation:

$$
A^{*}=\left\{\left(u_{i}(x)\left|\max _{i} \times u_{i}(x)\right| i=1,2, \ldots, n\right)\right\}
$$

or alternative gaps can be increased to build the best new alternative $A^{*}$ to reach the desired level of each criterion. And also:

$$
u_{i}(x)=\sum_{j=1}^{n} w_{j} r_{i j}(x)
$$

Where Ui(x) shows the utility of alternative- $i$, and $i=$ $1,2, \ldots, n ;$. While wj indicates the weight of criteria $j$. In the equation $\operatorname{rij}(x)$ is a normalized rating chosen from the $i$ - 
alternative which corresponds to the $j$-criterion for all equivalent units; assuming all criteria are independent. In addition, the normalized rating chosen $\operatorname{rij}(x)$ from the $i$ alternative which relates to the $j$-criteria can be defined as follows [7]:

Form 1

- For the benefit criteria (bigger is better), $\mathrm{r}_{\mathrm{ij}}(\mathrm{x})=\mathrm{x}_{\mathrm{ij}} / \mathrm{x}_{\mathrm{j}}^{*}$, where $x_{j}^{*}=\max _{i} x_{i j}$ or make $x_{j}^{*}$ the desired level, and with condition $0<=r_{i j}(x)<=1$.

- For cost criteria (smaller is better), $\mathrm{r}_{\mathrm{ij}}(\mathrm{x})=\left(1 / \mathrm{x}_{\mathrm{ij}}\right) /\left(1 / \mathrm{x}_{\mathrm{j}}^{*}\right)=$ $\left(\max _{\mathrm{i}} \mathrm{x}_{\mathrm{j}}^{*}\right) /\left(\mathrm{x}_{\mathrm{ij}}\right)$ or keep making $\mathrm{x}_{\mathrm{j}}{ }_{\mathrm{j}}$ the desired level.

Form 2

- For benefit criteria (bigger is better), $\left.\mathrm{r}_{\mathrm{ij}}(\mathrm{x})=\mathrm{x}_{\mathrm{ij}}-\mathrm{x}_{\mathrm{j}}^{-}\right) /\left(\mathrm{x}_{\mathrm{j}}^{*}-\right.$ $x_{j}^{-}$), where $x_{j}^{*}=\max _{i} x_{i j}$ dan $x_{j}^{-}=\min _{i} x_{i j}$ or make $x_{j}^{*}$ the desired level (the best) and $\mathrm{x}_{\mathrm{j}}$ as the least desirable (the worst) level.

- For cost criteria (smaller is better), $\mathrm{r}_{\mathrm{ij}}(\mathrm{x})=\left(\mathrm{x}_{\mathrm{j}}^{-}-\mathrm{x}_{\mathrm{ij}}\right) /\left(\mathrm{x}_{\mathrm{j}}^{-}-\right.$ $\mathrm{x}_{\mathrm{j}}^{*}$ ).

Therefore, the performance of synthesized are:

$$
p_{i}=\sum_{j=1}^{m} w_{j} r_{i j}
$$

Where pi is the synthesis performance value or preference value of the $i$-alternative; $\mathrm{w}_{\mathrm{j}}$ shows the weighting of the criteria to $\mathrm{j}$; $r_{i j}$ is a normalized rating chosen from the $i$-alternative to the $j$ criterion to become an equivalent unit; and the criteria are assumed to be independent of each other. If the unit matrix is a unit equivalent performance, we do not need to transfer data matrix into which the selected normalized grading scale.

\section{RESEARCH METHODS}

\section{A. Analisis of System Functional}

To determine the requirements for system functionality, a design tool using UML is needed:

\section{Flowchart Diagram}

Flowchart is a diagram that represents the type of algorithm or steps sequential instruction in the system. Fig. 1 shows the business system flow starting from a user login to the backend, then in the backend system, a user can choose the menus to manage disaster data, SAW method master data, and user management. The disaster data will be used as the value of fuzzy input data into the SAW method.

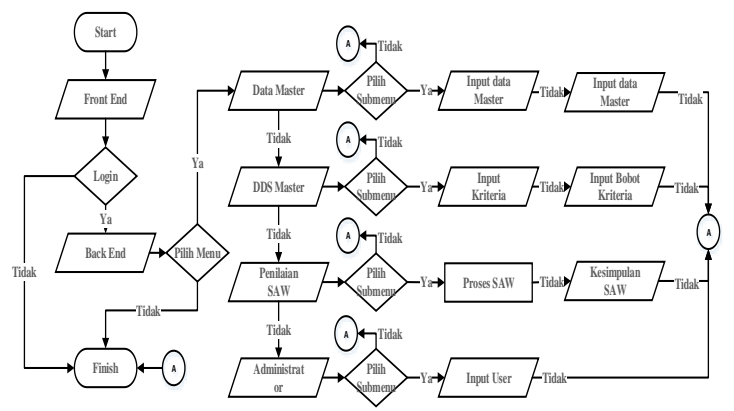

Fig. 1. Flowchart Diagram

\section{Class Diagram}

Class diagram is a diagram illustrating the interactions and relationships between classes in the system. Figure 2 shows the ten classes proposed in system design. Including class of user, year, barracks, logistics, refugees, human resources, damage, criteria, alternatives, and evaluation of SAW.
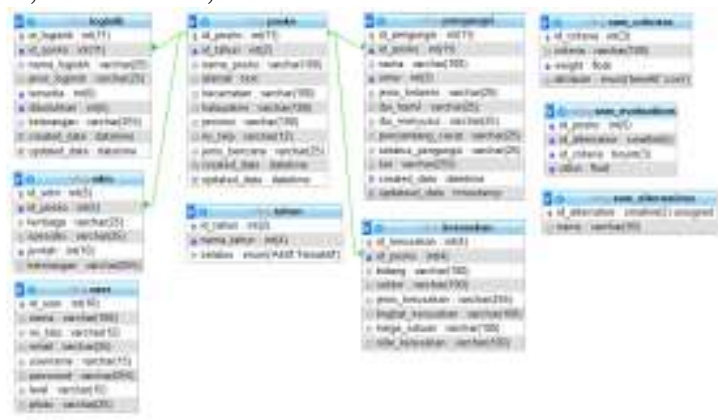

Fig. 2. Class Diagram

\section{B. Analysis of Fuzzy Method}

Here are the steps to determine the input value using the Tahssani Fuzzy Database Model method.

1. Determine the criteria that will be used as a reference for decision making..

TABLE I. Criteria

\begin{tabular}{|c|c|c|}
\hline Variable & Criteria & Attribute \\
\hline C1 & $\begin{array}{c}\text { The number of } \\
\text { victims }\end{array}$ & Cost \\
\hline C2 & Capacity of barrack & Cost \\
\hline C3 & Logistics Needs & Cost \\
\hline C4 & $\begin{array}{c}\text { Availability of health } \\
\text { facilities }\end{array}$ & Benefit \\
\hline C5 & $\begin{array}{c}\text { Damaged public } \\
\text { facilities }\end{array}$ & Benefit \\
\hline
\end{tabular}

The criteria are divided into two categories, namely benefits and costs. Criteria are said to be a benefit if the criteria are to be maximized while criteria are categorized as benefits if the criteria are to be minimized.

2. Describe the Membership Function

Membership function is a curve showing the mapping of points of data input into the value of its members.

3. Fuzzification

Fuzzification is the conversion of firm values to fuzzy values. Variable Number of Victims is converted with fuzzy numbers as follows:

TABLE II. The number of victims

\begin{tabular}{|l|l|l|}
\hline \multicolumn{1}{|c|}{$\begin{array}{c}\text { The number of } \\
\text { victims }\end{array}$} & \multicolumn{1}{|c|}{ Category } & Value \\
\hline$<50$ people & Low & 0 \\
\hline $51-125$ people & Moderate & 0,33 \\
\hline $125-250$ people & High & 0,67 \\
\hline$>251$ people & Very high & 1 \\
\hline
\end{tabular}

Variable Barrack Capacity is converted with fuzzy numbers as follows: 
TABLE III. Capacity of barrack

\begin{tabular}{|l|l|l|}
\hline Capacity of barrack & Category & Value \\
\hline$<50 \mathrm{~m}^{2}$ & Low & 0 \\
\hline $51-125 \mathrm{~m}^{2}$ & Moderate & 0,33 \\
\hline $125-250 \mathrm{~m}^{2}$ & High & 0,67 \\
\hline$>251 \mathrm{~m}^{2}$ & Very high & 1 \\
\hline
\end{tabular}

Logistics Needs variable converted by fuzzy numbers as follows:

TABLE IV. Logistics Needs

\begin{tabular}{|l|l|l|}
\hline \multicolumn{1}{|c|}{ Logistics Needs } & \multicolumn{1}{c|}{ Category } & Value \\
\hline$<0,50$ & Low & 0 \\
\hline $0,51-0,75$ & Moderate & 0,33 \\
\hline $0,75-1,00$ & High & 0,67 \\
\hline$>1,10$ & Very high & 1 \\
\hline
\end{tabular}

Variable Availability of health facilities is converted with fuzzy numbers as follows:

TABLE V. Availability of health facilities

\begin{tabular}{|l|l|l|}
\hline $\begin{array}{c}\text { Availability of } \\
\text { health facilities }\end{array}$ & \multicolumn{1}{|c|}{ Category } & Value \\
\hline$<2$ facilities & Low & 0 \\
\hline $3-5$ facilities & Moderate & 0,5 \\
\hline$>6$ facilities & High & 1 \\
\hline
\end{tabular}

Variable damage public facilities converted with fuzzy numbers as follows:

TABLE VI. Kerusakan Fasilitas Kesehatan

\begin{tabular}{|l|l|l|}
\hline $\begin{array}{c}\text { Kerusakan Fasiliats } \\
\text { Umum }\end{array}$ & \multicolumn{1}{|c|}{ Category } & Value \\
\hline$<2$ facilities & Low & 0 \\
\hline $3-5$ facilities & Moderate & 0,5 \\
\hline$>6$ facilities & High & 1 \\
\hline
\end{tabular}

4. Fuzzyfication Query

Fuzzyfication Query is assumed to be a conventional (non-fuzzy) DBMS query that will try to create and implement a basic system of query logic.

TABLE VII. Fuzzyfication Query

\begin{tabular}{|c|c|c|c|c|c|}
\hline \multirow{2}{*}{ Alternatif } & \multicolumn{5}{|c|}{ Kriteria } \\
\cline { 2 - 6 } & C1 & C2 & C3 & C4 & C5 \\
\hline Barrack 1 & 0,33 & 0,67 & 0,33 & 1 & 0 \\
\hline Barrack 2 & 1 & 0,67 & 1 & 0 & 0,5 \\
\hline Barrack 3 & 1 & 0,33 & 1 & 0 & 0,5 \\
\hline Barrack 4 & 0,33 & 1 & 0,33 & 0,5 & 0 \\
\hline Barrack 5 & 0,67 & 1 & 0,67 & 0,5 & 1 \\
\hline
\end{tabular}

\section{Analysis of the SAW Method}

Once the input value obtained phases of the steps being taken in the SAW method is:
TABLE VIII. Criterion Weight

\begin{tabular}{|l|c|c|c|}
\hline \multicolumn{1}{|c|}{ Criteria } & Variable & Attribute & Weight \\
\hline $\begin{array}{l}\text { The number } \\
\text { of victims }\end{array}$ & $\mathrm{C} 1$ & Cost & 1.6 \\
\hline $\begin{array}{l}\text { Capacity of } \\
\text { barrack }\end{array}$ & $\mathrm{C} 2$ & Cost & 2.8 \\
\hline $\begin{array}{l}\text { Logistics } \\
\text { Needs }\end{array}$ & $\mathrm{C} 3$ & Cost & 3.2 \\
\hline $\begin{array}{l}\text { Availability } \\
\text { of health } \\
\text { facilities }\end{array}$ & $\mathrm{C} 4$ & Benefit & 1.8 \\
\hline $\begin{array}{l}\text { Damaged } \\
\text { public } \\
\text { facilities }\end{array}$ & $\mathrm{C} 5$ & Benefit & 1.4 \\
\hline
\end{tabular}

From Table VIII obtained by the weight values (W) with the

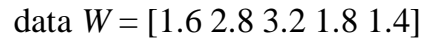

With alternatives

TABLE IX. Alternative

\begin{tabular}{|c|c|}
\hline Alternative & Variables \\
\hline Barrack 1 & $\mathrm{A} 1$ \\
\hline Barrack 2 & $\mathrm{A} 2$ \\
\hline Barrack 3 3 3 \\
\hline Barrack 4 & $\mathrm{A} 4$ \\
\hline Barrack 5 & $\mathrm{A} 5$ \\
\hline
\end{tabular}

Once an alternative is determined, then make the rating the suitability of each alternative on each criterion (Table X)

TABLE X. Suitability rating

\begin{tabular}{|c|c|c|c|c|c|}
\hline \multirow{2}{*}{ Alternatif } & \multicolumn{5}{|c|}{ Kriteria } \\
\cline { 2 - 6 } & C1 & C2 & C3 & C4 & C5 \\
\hline A1 & 0,33 & 0,67 & 0,33 & 1 & 0 \\
\hline A2 & 1 & 0,67 & 1 & 0 & 0,5 \\
\hline A3 & 1 & 0,33 & 1 & 0 & 0,5 \\
\hline A4 & 0,33 & 1 & 0,33 & 0,5 & 0 \\
\hline A5 & 0,67 & 1 & 0,67 & 0,5 & 1 \\
\hline
\end{tabular}

From Table X, the decision matrix obtained as follows.

$$
X=\left(\begin{array}{ccccc}
0,33 & 0,67 & 0,33 & 1 & 0 \\
1 & 0,67 & 1 & 0 & 0,5 \\
1 & 0,33 & 1 & 0 & 0,5 \\
0,33 & 1 & 0,33 & 0.5 & 0 \\
0,67 & 1 & 0,67 & 0.5 & 1
\end{array}\right)
$$

To normalize the $\mathrm{X}$ matrix into the $\mathrm{R}$ matrix requires multiplication of the criterion weights $(\mathrm{W})$ with the $\mathrm{X}$ matrix. For the calculation of the matrix $\mathrm{R}$ requires the benefit or cost value criteria in Table VII. Normalized matrix calculation as follows.

For C1

$$
\begin{aligned}
& R_{11}=\frac{0,33}{\min \{0,33110,330,67\}}=\frac{0,33}{0,33}=1 \\
& R_{21}=\frac{1}{\min \{0,33110,330,67\}}=\frac{1}{0,33}=0,33 \\
& R_{31}=\frac{1}{\min \{0,33110,330,67\}}=\frac{1}{0,33}=0,33
\end{aligned}
$$




$$
\begin{aligned}
& R_{41}=\frac{0,33}{\min \{0,33110,330,67\}}=\frac{0,33}{0,33}=1 \\
& R_{51}=\frac{0,67}{\min \{0,33110,330,67\}}=\frac{0,67}{0,33}=0.67
\end{aligned}
$$

\section{For $\mathrm{C} 2$}

$R_{12}=\frac{0,67}{\min \{0,670,670,3311\}}=\frac{0,67}{0,33}=0,49$

$R_{22}=\frac{0,67}{\min \{0,670,670,3311\}}=\frac{0,67}{0,33}=0,49$

$R_{32}=\frac{0,33}{\min \{0,670,670,3311\}}=\frac{0,33}{0,33}=1$

$R_{42}=\frac{1}{\min \{0,670,670,3311\}}=\frac{1}{0,33}=0,33$

$R_{52}=\frac{1}{\min \{0,670,670,3311\}}=\frac{1}{0,33}=0,33$

\section{For C3}

$R_{13}=\frac{0,33}{\min \{0,33110,330,67\}}=\frac{0,33}{0,33}=1$

$R_{23}=\frac{1}{\min \{0,33110,330,67\}}=\frac{1}{0,33}=0,33$

$R_{33}=\frac{1}{\min \{0,33110,330,67\}}=\frac{1}{0,33}=0,33$

$R_{43}=\frac{0,33}{\min \{0,33110,330,67\}}=\frac{0,33}{0,33}=1$

$R_{53}=\frac{0,67}{\min \{0,33110,330,67\}}=\frac{0,67}{0,33}=0,49$

For $\mathrm{C} 4$

$R_{14}=\frac{\max \left\{\begin{array}{lllll}1 & 0 & 0 & 0,5 & 0,5\end{array}\right\}}{1}=\frac{1}{1}=1$

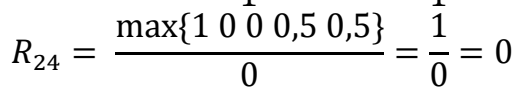

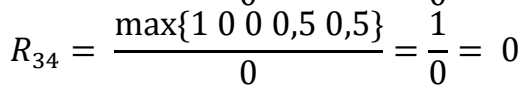

$R_{44}=\frac{\max \left\{\begin{array}{lllll}1 & 0 & 0 & 0,5 & 0,5\}\end{array}\right.}{0,5}=\frac{1}{0,5}=0,5$

$R_{54}=\frac{\max \left\{\begin{array}{lllll}1 & 0 & 0 & 0,5 & 0,5\end{array}\right\}}{0,5}=\frac{1}{0,5}=0,5$

\section{For C5}

$R_{15}=\frac{\max \left\{\begin{array}{lllll}0 & 0,5 & 0,5 & 0 & 1\end{array}\right\}}{0}=\frac{1}{0}=0$

$R_{25}=\frac{\max \left\{\begin{array}{lllll}0 & 0,5 & 0,5 & 0 & 1\end{array}\right\}}{0,5}=\frac{1}{0,5}=0,5$

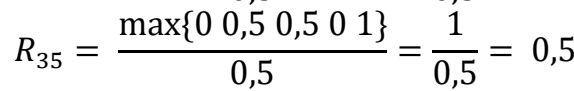

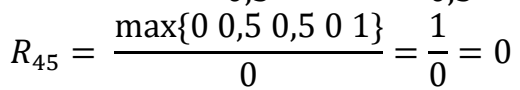

$R_{55}=\frac{\max \left\{\begin{array}{lllll}0 & 0,5 & 0,5 & 0 & 1\end{array}\right\}}{1}=\frac{1}{1}=1$

Then obtained a matrix as follows

$$
R=\left(\begin{array}{ccccc}
1 & 0,49 & 1 & 1 & 0 \\
0,33 & 0,49 & 0,33 & 0 & 0,5 \\
0,33 & 1 & 0,33 & 0 & 0,5 \\
1 & 0,33 & 1 & 0,5 & 0 \\
0,49 & 0,33 & 0,49 & 0,5 & 1
\end{array}\right)
$$

Furthermore, the ranking process done by the sum of the normalized R matrix multiplication with the weight vector. The ranking result in the Table XI.

$\mathrm{P}_{1}=(1,6 \times 1)+(2,8 \times 0,49)+(3,2 \times 1)+(1,8 \times 1)+(1,4 \times 0)$ $=7,979104$

$\mathrm{P}_{2}=(1,6 \times 0,33)+(2,8 \times 0,49)+(3,2 \times 0,33)+(1,8 \times 0)+(1,4$ $\times 0,5)=3,663104$

$\mathrm{P}_{3}=(1,6 \times 0,33)+(2,8 \times 1)+(3,2 \times 0,33)+(1,8 \times 0)+(1,4 \times$ $0,5)=5,084$

$\mathrm{P}_{4}=(1,6 \times 1)+(2,8 \times 0,33)+(3,2 \times 1)+(1,8 \times 0,5)+(1,4 \times 0)$ $=6,624$

$\mathrm{P}_{5}=(1,6 \times 0,49)+(2,8 \times 0,33)+(3,2 \times 0,49)+(1,8 \times 0,5)+$ $(1,4 \times 1)=5,588179$

TABLE XI. Ranking Results

\begin{tabular}{|c|c|c|c|}
\hline Alternative & Variable & $\begin{array}{c}\text { Preference } \\
\text { Value }\end{array}$ & Rank \\
\hline Barrack 1 & A1 & 7,979104 & 1 \\
\hline Barrack 2 & A2 & 3,663104 & 5 \\
\hline Barrack 3 & A3 & 5,084 & 4 \\
\hline Barrack 4 & A4 & 6,624 & 2 \\
\hline Barrack 5 & A4 & 5,588179 & 3 \\
\hline
\end{tabular}

\section{RESULTS}

\section{A. User Interface}

The following will show the results of the system design that has been developed using the PHP programming language

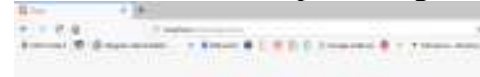

Fig. 3. Login Page

According to the analysis of the system functionality, the user is required to login in Fig. 3 before being able to access Front End

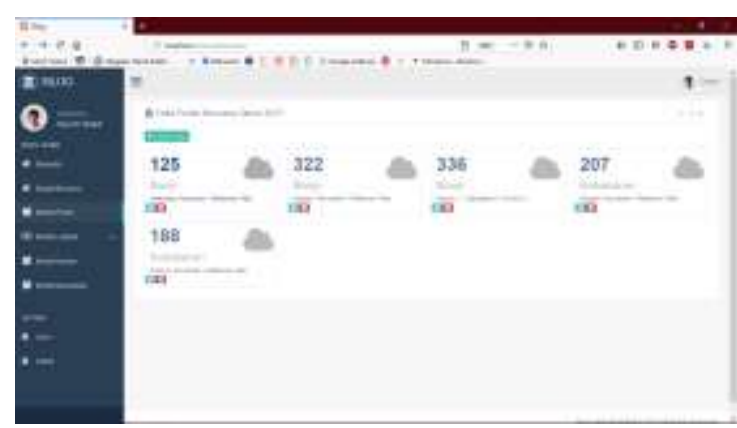

Fig. 4. Front End

After a user is on the front end page in Fig. 4, a user can choose the menu management data barrack, logistics, victims, damage and, decision support. 


\section{B. Fuzzy Simple Additive Weighting Method Process}

In order to support the decision, the SAW method is required to determine the criteria and attributes, then specify the value of its weight. From Fig. 5 we know the weight value (W) with the data $W=[1,62,83,21,81,4]$.

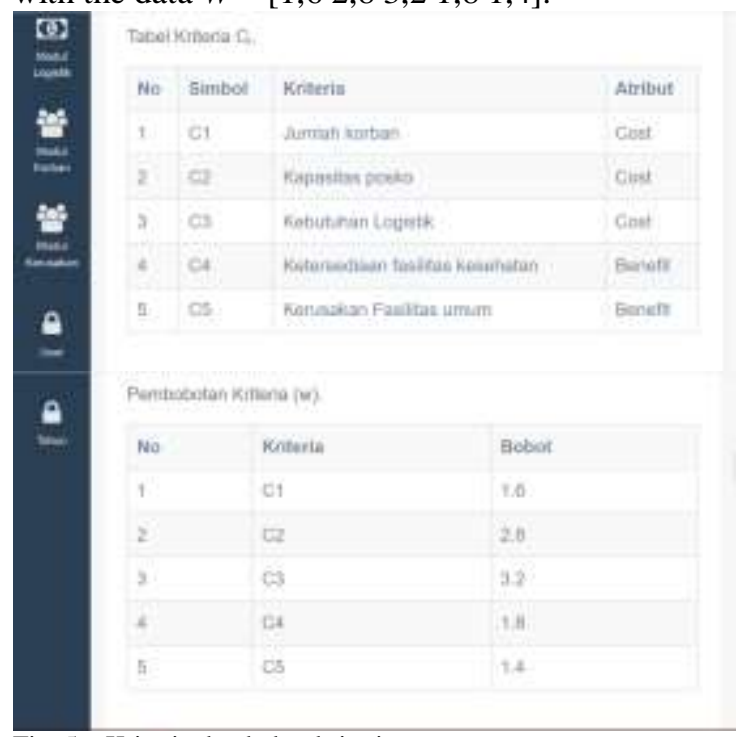

Fig. 5. Kriteria dan bobot kriteria

The data collected in the database is processed using fuzzy database model tahani method and then used as suitability rating of each alternative on each criterion. The results of fuzzy values shows in Fig. 6.

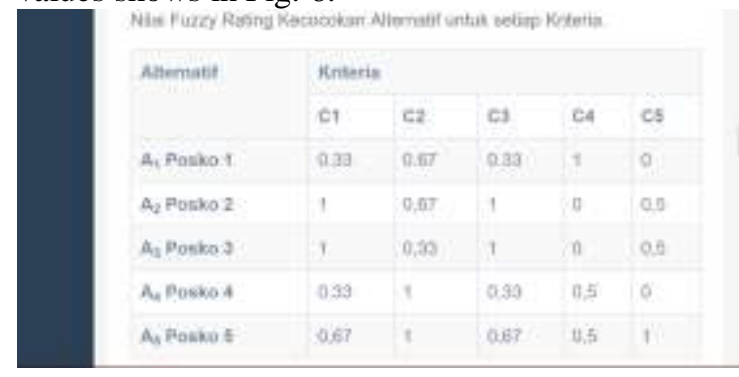

Fig. 6. Suitability rating (X)

Based on the classification criteria of Fig. 5 where criteria 1 , criterion 2, criterion 3 in cost and criterion 4 , criterion 5 in benefits, the calculation result to normalize the $\mathrm{X}$ matrix can seen in Fig. 7.

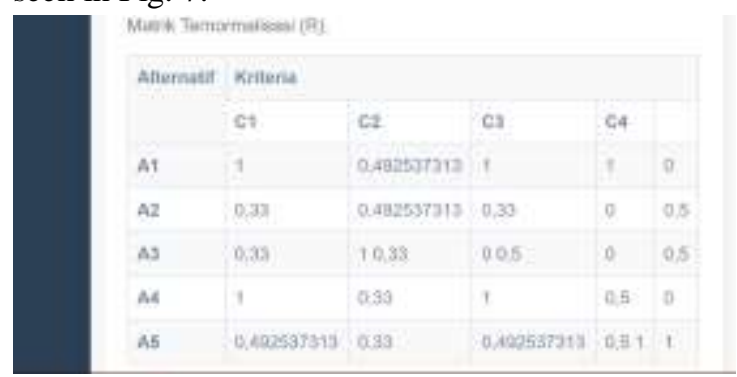

Fig. 7. Normalized matrix (R)

Furthermore, the ranking process done by the sum of the normalized $\mathrm{R}$ matrix multiplication with the weight vector. The ranking result shows in Fig. 8.
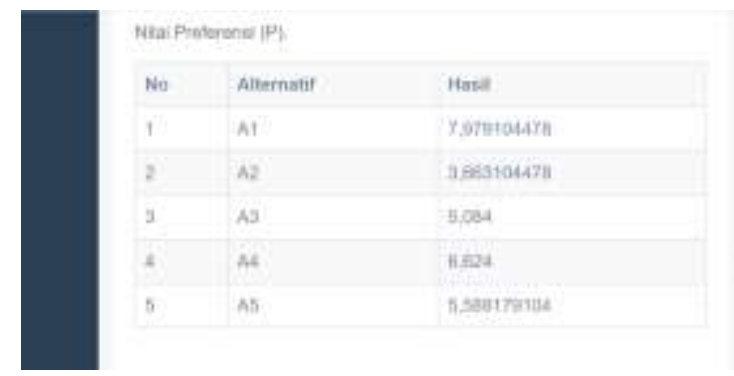

Fig. 8. Ranking result

\section{CONCLUSION}

The use of fuzzy queries in the fuzzy database model tahani method successfully determines the degree of membership that can be used as an input value on the suitability rating of the SAW method and the output is rank result value with the largest preference is 7.98 at A1 and the smallest preference is 3.66 at A2. The application of the Fuzzy SAW method from this study can help BPBD of Malang to determining the policy priorities of natural disaster barrack selection.

\section{REFERENCES}

[1] BNPB, "Data Informasi Bencana Indonesia (DIBI)." [Online]. Available: http://dibi.bnpb.go.id/dibi/. [Accessed: 28-Jul-2019].

[2] N. Alifah and A. Cahyo, "Analisis dan erancangan desain sistem informasi perpustakaan sekolah berdasarkan kebutuhan sistem," Berk. Ilmu Perpust. dan Inf., vol. 14, no. 1, pp. 76-78, 2018.

[3] I. Widaningrum, "Evaluasi Kinerja Dosen Menggunakan Metode Fuzzy Multi-Attribute Decision Making (FMADM) Dengan Pengembangan ( Studi Kasus: Universitas Muhammadiyah Ponorogo )," Semin. Nas. Teknol. Inf. dan Multimed., pp. 61-66, 2013.

[4] B. Prasetiyo, N. Baroroh, and D. E. Rufiyanti, "Fuzzy Simple Additive Weighting Method in the Decision Making of Human Resource Recruitment," Lontar Komput. J. Ilm. Teknol. Inf., vol. 7, no. 3, p. 174, 2016.

[5] R. Efendi, Ernawati, and R. Hidayati, “Aplikasi Fuzzy Database Model Tahani Dalam Memberikan Rekomendasi Pembelian Rumah Berbasis Web," Pseudocode, vol. 1, pp. 32-43, 2014.

[6] R. Helilintar, W. W. Winarno, and H. Al Fatta, "Penerapan Metode SAW dan Fuzzy Dalam Sistem Pendukung Keputusan Penerimaan Beasiswa," Citec, vol. 3, no. 2, pp. 89-101, 2016.

[7] C. Dsn, "DSS SAW Method." [Online]. Available: https://cahyadsn.phpindonesia.id/extra/saw.php. [Accessed: 18-Dec2018]. 